\title{
Theoretical and Practical Aspects of Using Scaling Factor Method to Characterize Operational Solid Radioactive Waste Producible at Nuclear Power Plants
}

Keywords:

nuclear power plants, radioactive waste, characterization, scaling factors, key nuclides, difficult to measure radionuclide, correlation factor.

\begin{abstract}
Brief review of the most well-known analytical and methodological materials devoted to the theory and practice in characterization of radioactive waste (RAW) generated at NPPs is presented. The basic principles of method for building scaling factors (SF) and the main features of SF application in technological chain of RAW management are disclosed. It was demonstrated that the basis that allows using the SF methodology is the availability of functional relationships between the activities of various radionuclides, which are simultaneously accumulated during reactor campaign and contamination of various materials. In the course of special investigation, it is needed as follows: to take a representative sample of waste from each stream of materials subject to radiation monitoring; in the laboratory to determine the content of all radionuclides to be certified; when using the methods of statistical data analysis, to identify the key nuclides $(\mathrm{KN})$ and calculate the SF average values, which make it possible, based on the results of gamma-spectrometry of KN content, to estimate alpha and beta-emitting radionuclide activities in RAW packages, whose measurement demands high material costs and time (for DTM - difficult to measure radionuclides). An illustration of impact of different factors and mechanisms, which form DTM nuclides and KN content ratio in solid waste characteristic of RBMK-type reactors, is delivered. The basic requirements and procedures, which are to be reflected in the method to characterize solid RAW from Chornobyl NPP for DTM radionuclides certification using the SF, are determined.
\end{abstract}

\section{Introduction}

Radioactive waste (RAW) is produced from a range of activities resulting in waste streams varying by its form, activity, physical state, etc. The RAW sources are often called as "point of origin" [1], which also contain each nuclear power plant (NPP). During the normal operation of reactor installations or during a NPP decommissioning, a large amount of RAW is generated [2]. Appropriate monitoring of chemical and radiochemical parameters of RAW within the entire life cycle of waste management, and careful testing of the quality of final waste forms and waste packages, are the principal components of any waste management strategy [3]. A failure in monitoring proce- dures at any of its steps can cause important consequences, not only in follow-up steps, but, in some cases it brings to generation of waste packages, which are not compliant with the waste acceptance criteria for long-term storage or burial. The characterization of RAW includes establishing a list of radionuclides, together with their specific activity, inside each package $[3,4]$. The evaluation of radionuclide activities in radwaste is required for its disposal in final repositories. The inventory of radionuclides to be declared with each waste form is numerous and diversified (alpha- and/or beta-emitters). Some of these radionuclides are easy to measure (ETM) with using NDA (non-destructive assay) or DA (destructive assay), but most of them are difficult to measure (DTM) and need 
DA in a laboratory or a calculation with using special codes (e.g. pure beta-emitters). Some of them are impossible to measure (ITM) even in a laboratory. However, it is not true for the other techniques for waste characterization, namely, NDE (non-destructive evaluation), NDA or DA. The technology available today for NDE and NDA is reliable, but costly.

To solve the existing problem, numerous studies were conducted, which allowed establishing quantitative relationships between the activities of ETM and DTM radionuclides in other RAW streams [5]. In subsequent years, the results were confirmed by more detailed studies and made the basis of scaling factor (SF) methodology [6-9].

Similar difficulties hamper full and large-scale characterization of RAW accumulated in large quantities within the territory of Chornobyl NPP (ChNPP) Exclusion Zone. In addition, beside various RAW formed as a result of mitigation of ChNPP Unit 4 accident in 1986 and located in temporary repositories and at ChNPP Shelter object, other RAW sources also exist in the Exclusion Zone: producible under decommissioning work, sites for interim storage of RAW, works related to decontamination of equipment and materials $[2,10]$.

To characterize operational solid RAW of ChNPP origin, introduction of SF methodology (SFM) in Waste Characterization Systems was recommended $[11,12]$. This approach also reflects the policies of IAEA and WANO to extend possible application of SFM to characterize the RAW producible during decommissioning of nuclear facilities and problematic/ legacy wastes, which are to be retrieved from existing storage structures.

The aim of this work is to study SFM basic principles and those used in characterization of different RAW generated in a reactor installation, and also to highlight the main requirements and procedures, which are prescribed in Technique of SF identification to characterize solid RAW accumulated over normal operation period of ChNPP Units.

\section{Basic principles and international standards used in the field of scaling factor methodology}

The disposal of RAW requires the knowledge of its radioactivity content in terms of specific radionuclide concentrations. This information is used by a repository operator and/or regulator to trace radionuclide inventories and concentrations, which are generally limited by repository safety assessment and operating licence [6].
Many of important long-lived radionuclides contained in the RAW are DTM from outside a waste package with using non-destructive techniques because they are of low energy, and non-penetrated by beta or alpha emitting nuclides (i.e. non-gamma emitters). Identification of these DTM nuclides requires the creation of methods, which, in general, involve analysis of waste samples with using complex chemical analyses to separate various radionuclides for measurement. This method is not practical for large amount of waste packages.

Several theoretical techniques for nuclide determination, such as modelling of activation in structural components of reactor core and prediction of fuel nuclide composition in nuclear fuel with using the codes, such as MCNP or SCALE, can be applied $[6,8]$. However, it is difficult to predict the nuclide content in very low level-, low- and intermediate-level RAW by purely theoretical methods due to physical and chemical processes involved in RAW generation. Therefore, for such situations it is recommended to implement experimental measurement techniques [7]. Moreover, experimental measurements of nuclide content are the basic tool for validation of theoretical predictions. The main steps in implementing the SFM for RAW characterization in NPPs are shown in the Fig. 1.

A methodology for empirical determination of SFs is described in International Standard ISO 21238:2007 [7]. The SFM is widely used to evaluate DTM nuclides. The SFM is based on development of a correlation between ETM gamma-emitting nuclides (key nuclides $\mathrm{KN}$ ) and DTM nuclides, which are contaminated by different materials in nuclear reactor [6]. The activities of DTM nuclides in waste packages are estimated by KN activity measurements and subsequent multiplication of this value by SF coefficients calculated on the basis of radionuclide data obtained by sampling and radiochemical analysis (according to established ratios of radioactive concentrations of DTM nuclides/KN). The document [7] gives guidelines for the SFs used in the characterization of RAW producible in water-cooled NPPs and other types of reactor.

One of the most important and responsible steps in successful application of SFM is SF determination for all radiologically significant radionuclides, which must be measured and certified in relation to State regulation. As noted in [4], in many countries, characterization is carried out, mainly, to ensure radiation safety of personnel during the RAW management, nuclear safety and control of commercial product losses. Under the absence of control of long-lived radionuclides, the solu- 


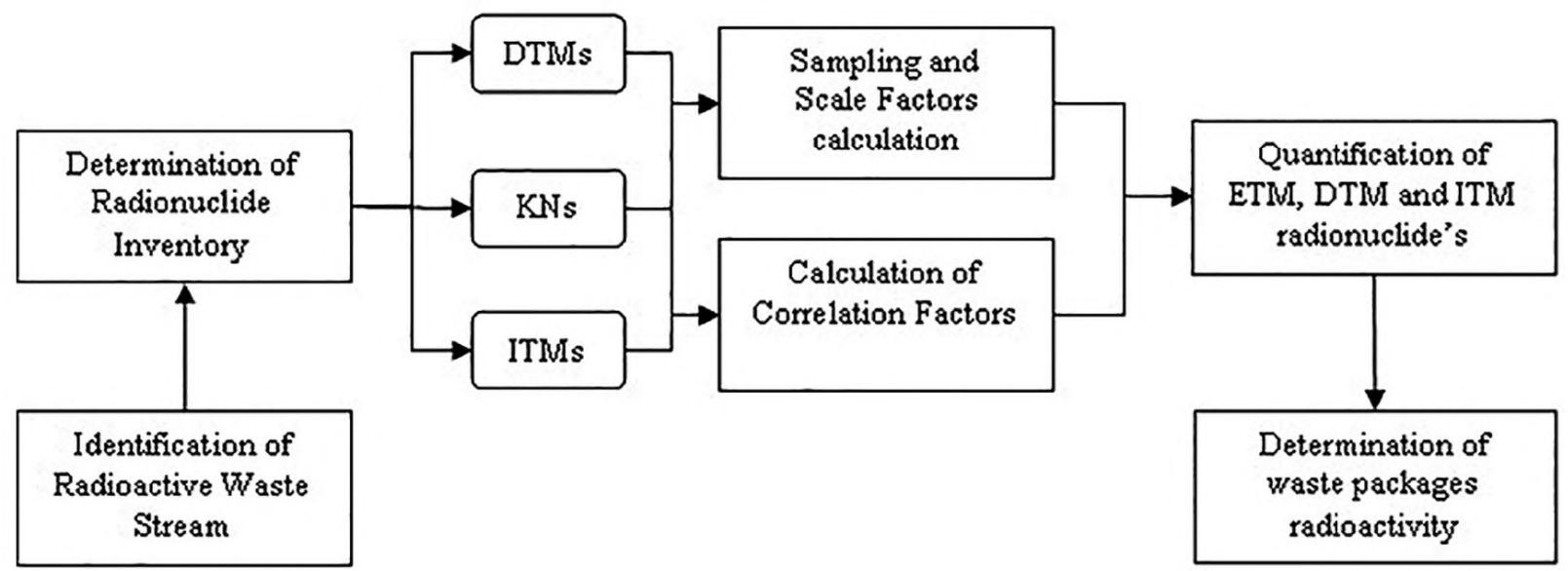

Fig. 1. SF methodology for RAW characterization in NPPs

tion of tasks to assess long-term safety of RAW dumps is difficult and, practically, impossible. For solid RAW accumulated during the normal operation of ChNPP, the list of radionuclides to be certified includes 23 radioactive isotopes, whose majority refers to DTM long-lived radionuclides [13].

Nowadays, SFM methodology was developed to be used in all NPP types: Boiling Water Reactor (BWR), Pressurized Water Reactors (PWR), Gas-cooled Reactor (GCR), water-cooled, water-moderated power reactor (WWER), High Power Channel-type Reactor (RBMK), Pressurized Heavy Water Reactor (PHWR), and others. They are, primarily, applied to operating reactors, but are also used for shutdown reactors and reactors undergoing decommissioning (Japan, Spain, Slovakia, the USA, Lithuania and Ukraine) [6]. As it is described below, some special considerations may be required for reactors undergoing decommissioning, as well as for those, which may have had major fuel damage or environmental contamination incident.

It is important to note the following thing. First, the sampling practices, calculation model and data maintenance practices may differ in various countries (for example, sampling at some stages of development process and/or sampling of waste streams). As a part of this article, we will not discuss this issue in detail, except for discussing the importance of separating waste into streams, which will be done below. An example of basic principles to determine the amount of samples, which are to be taken, may be found in [16].

Second, in the majority of countries, two main methods to calculate mean SF values are used: arithmetic mean (such as Japan, Slovenia and the UK) and geometric (logarithmic) mean (such as Brazil, Canada, France, the Republic of Korea, Italy, Spain, Sweden, Ukraine and the USA). The SF "mean value" is based on the as- sumption that the relationship between a KN and a DTM nuclide is linear over the range of activities of interest. The arithmetic mean will tend to produce a conservative (i.e. high) value, while the geometric mean will tend to produce a more representative average value when the data points are spread over several orders of magnitude. The Fig. 2 shows an example illustrating a degree of SF value overestimation with using a second data analysis method. Other countries, such as Germany, Hungary, Lithuania, Mexico and Slovakia, use a logarithm regression analysis to calculate the SF values.

Third, the KN and DTM grouping practices may also differ. In theory, $\mathrm{KN}$ selection is based on considerations relating to production mechanism, transport parameters and stream exposure in various processes. In practice, the main criterion is the ability to show that a correlation exists between the KN and the DTM nuclide. The Table 1 shows the results of established correlations between various radionuclides in the spectrum of radioactive contamination of waste, and identifies the best $\mathrm{KN}$ for a group of radionuclides united by general nature of their origin $[1,3,6,11,14,15]$. In all cases, the important point to be considered is, whether or not, $\mathrm{KN}$ and DTM nuclides show an 'acceptable' correlation for given circumstances. The ultimate determinant in establishing a viable $\mathrm{KN}$ is that, which is easy measurable with using gamma-spectrometry available at the point of generation or place for packaging for disposal.

Fourth, there are some cases where no reliable correlation has been found between KN and DTM nuclides. For example, development of SFs for ${ }^{3} \mathrm{H}$ and ${ }^{14} \mathrm{C}$ has been problematic in the USA for some waste streams [6]. In many of these cases, average values, theoretical values or upper bound values were used instead of SF calculated values (ITM, see Fig. 1). 


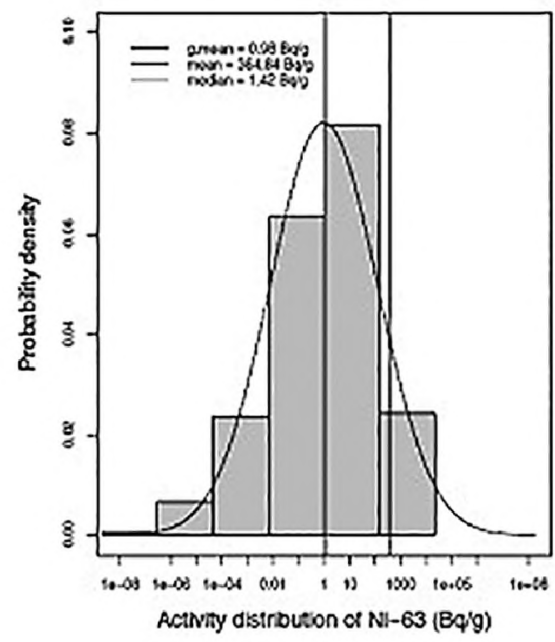

a

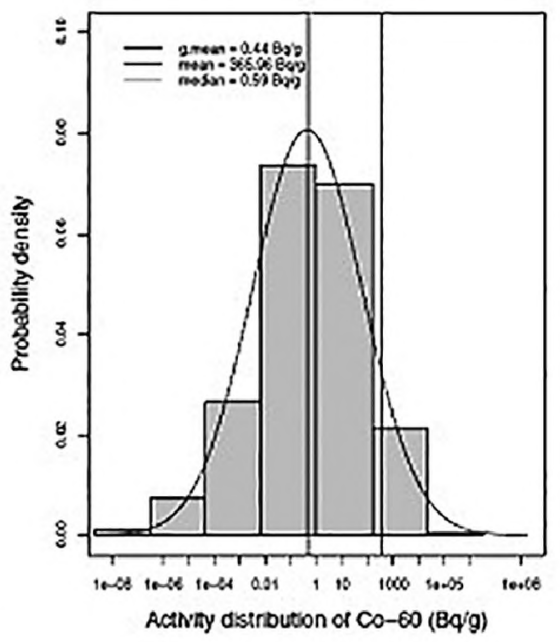

b

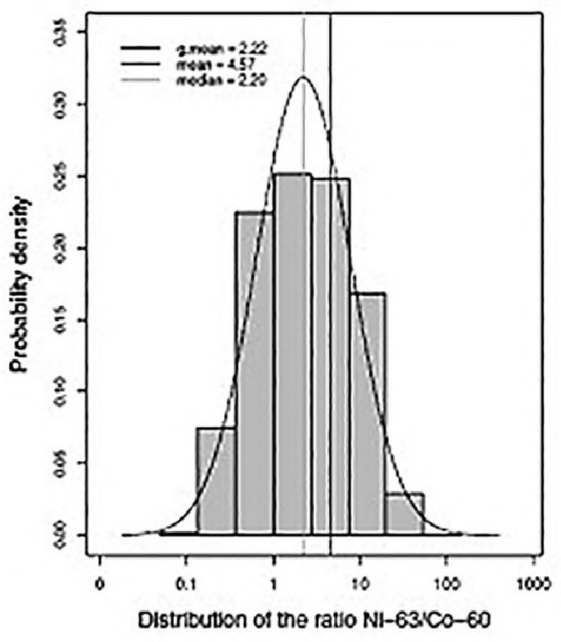

C

Fig. 2. Distribution of Ni-63 (a) and Co-60 (b) logarithm specific activities and their ratio logarithm (c) in irradiated copper [9]. Statistic parameters such as geometric mean (g. mean), mean and median, are represented together on the background of normal logarithmic curve

Table 1. Radionuclides to be, apparently, found in spent fuel treatment facility and solid RAW of normal and accident origin

\begin{tabular}{|c|c|c|c|}
\hline \multirow{2}{*}{$\begin{array}{l}\text { Number of } \\
\text { group }\end{array}$} & \multicolumn{2}{|c|}{ Groups of radionuclides } & \multirow{2}{*}{$\begin{array}{l}\text { Key nuclides } \\
\text { (tracer) }\end{array}$} \\
\hline & general characteristics & nuclides & \\
\hline 1 & $\begin{array}{c}\text { Activation products } \\
\text { (cooling water and steels) }\end{array}$ & ${ }^{10} \mathrm{Be},{ }^{3} \mathrm{H},{ }^{14} \mathrm{C},{ }^{55} \mathrm{Fe},{ }^{57} \mathrm{Co},{ }^{58} \mathrm{Co},{ }^{60} \mathrm{Co},{ }^{59} \mathrm{Ni},{ }^{63} \mathrm{Ni}$, & ${ }^{60} \mathrm{Co}$ \\
\hline 2 & Platinum-group metals & ${ }^{107} \mathrm{Pd},{ }^{106}(\mathrm{Ru}+\mathrm{Rh}),{ }^{103} \mathrm{Ru},{ }^{106} \mathrm{Ru}$ & ${ }^{106} \mathrm{Ru}$ \\
\hline 3 & Fission products & ${ }^{134} \mathrm{Cs},{ }^{135} \mathrm{Cs},{ }^{137} \mathrm{Cs},{ }^{90} \mathrm{Sr},{ }^{129} \mathrm{~T},{ }^{99} \mathrm{Tc}{ }^{93} \mathrm{Zr},{ }^{94} \mathrm{Nb}$ & ${ }^{137} \mathrm{Cs},{ }^{60} \mathrm{Co}$ \\
\hline 4 & Lanthanides & ${ }^{144} \mathrm{Ce},{ }^{147} \mathrm{Pm},{ }^{151} \mathrm{Sm},{ }^{154} \mathrm{Eu},{ }^{155} \mathrm{Eu}$ & ${ }^{154} \mathrm{Eu}$ \\
\hline 5 & $\begin{array}{c}\text { Actinides } \\
\text { (similar chemical behavior) }\end{array}$ & ${ }^{244} \mathrm{Cm},{ }^{243} \mathrm{Cm},{ }^{242} \mathrm{Cm},{ }^{241} \mathrm{Am},{ }^{242 \mathrm{~m}} \mathrm{Am},{ }^{243} \mathrm{Am}$ & ${ }^{241} \mathrm{Am}$ \\
\hline 6 & $\begin{array}{c}\text { Actinides } \\
\text { (spent fuel particles in solid RAW) }\end{array}$ & $\begin{array}{c}{ }^{235} \mathrm{U},{ }^{236} \mathrm{U},{ }^{238} \mathrm{U},{ }^{237} \mathrm{~Np},{ }^{238} \mathrm{Pu},{ }^{239} \mathrm{Pu},{ }^{240} \mathrm{Pu},{ }^{241} \mathrm{Pu}, \\
{ }^{242} \mathrm{Pu},{ }^{241} \mathrm{Am},{ }^{243} \mathrm{Am}\end{array}$ & ${ }^{137} \mathrm{Cs},{ }^{60} \mathrm{Co}$ \\
\hline
\end{tabular}

And finally, the fifth one, RAW is produced from a range of activities resulting in waste streams varying by their form, activity, physical state, etc. The sources of RAW are often called as "point of origin" [1], which also include each NPP. On the example of Ignalina NPP, which is closest to Chornobyl NPP by reactor type, the main sources and transfer channels of radionuclides in the RBMK systems can be represented in the form of diagram shown in Fig. 3 .

The reactor core is the main contamination source due to generation of radionuclides during neutron capture or nuclear fission and activation of reactor core components. The diagram in Fig. 3 clearly demonstrates three main routes that contaminated coolant of main circulation circuit can be further transferred to the final waste. The found features of formation of radioactive contamination of various materials and stable ratios of radionuclide ac- tivities in their mixtures make the basis in using the SFM to characterize different RAW streams. The above-mentioned features dictate the need in establishing separate $\mathrm{SFs}$ for the streams differing in the nature of radioactive contamination occurrence.

\section{Practical SFM application and challenges}

The measurement of the $\mathrm{KN}$ activity in waste packages is performed by one of two methods:

direct gamma assay (at the energy level associated with the $\mathrm{KN}$ );

dose rate measurement in relation to activity conversion, where gross gamma dose rate is measured at some distance from waste package surface, and is used to assume $\mathrm{KN}$ activity via a calculation model. 


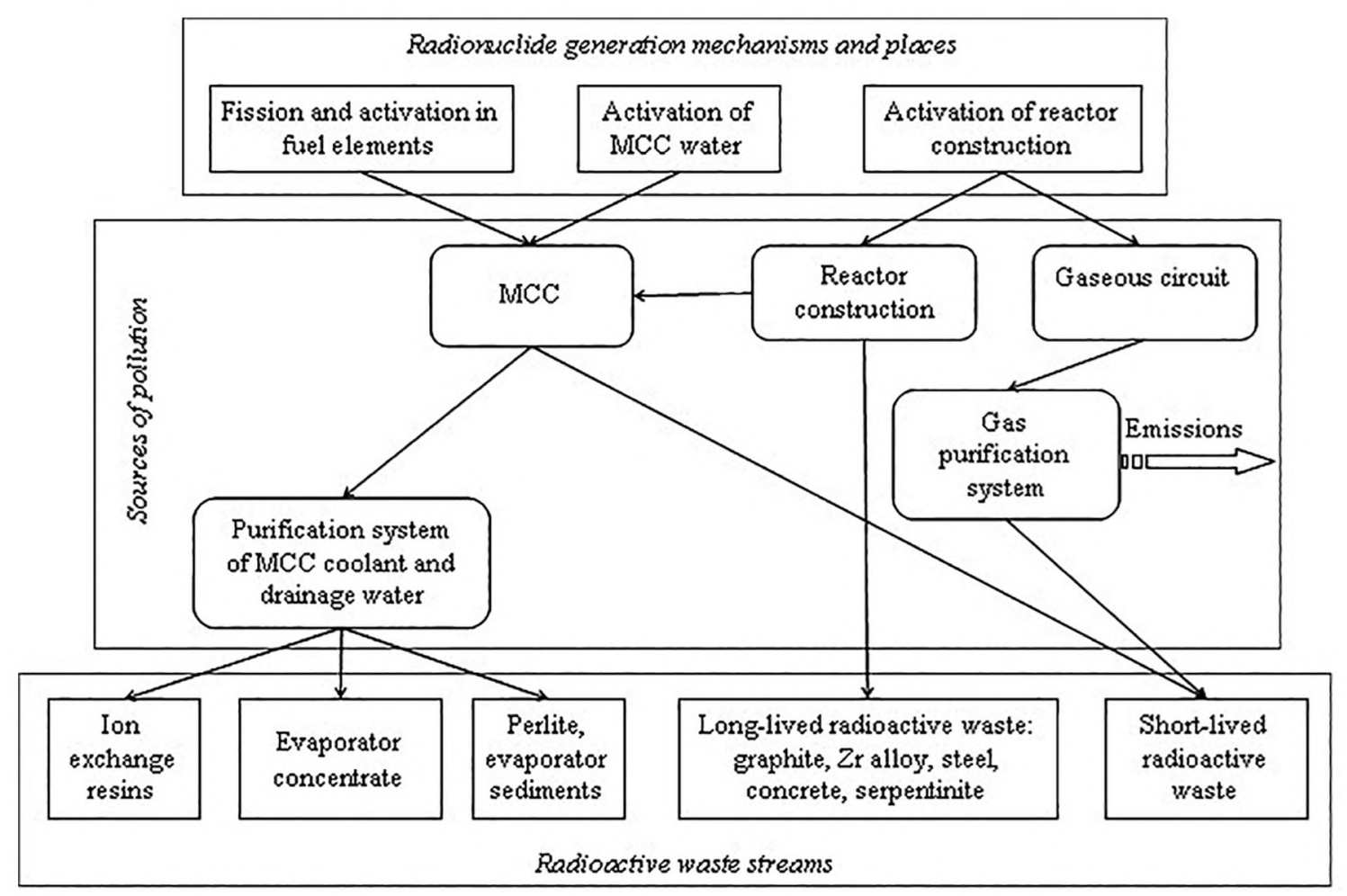

Fig. 3. Example of NPP radioactive waste streams. MCC - main circulation circuit [14]

While direct gamma assay can provide a more accurate $\mathrm{KN}$ measurement, it also requires more sophisticated equipment than the dose rate to activity conversion method. On the contrary, while dose rate to activity conversion method requires simple equipment, it still requires developing multiple conversion factors for various waste package types and geometries and/or waste types, and the use of well-defined measurement geometries in order to ensure result reproducibility.

In practice, the procedure for empirical determination of SFs values for all nuclides to be certified includes the following elements [6]:

sampling of waste streams (including determination of waste streams to be sampled, how many samples are required, how the samples are collected, etc.);

radiochemical analysis for the radionuclides of concern; analysis of data for correlation;

selection of $\mathrm{KN}$ based on evidence of correlation, modeling, or on established practice;

selection of appropriate SF calculation method (e.g. geometric mean, linear regression of logarithms);

assessment of feasibility in combining or grouping the data (for different waste streams, different reactor types, etc.);

systematic or additional sampling to validate the SFs, if the nature of waste contamination has changed (e.g. significant changes to major reactor component materials and/or indication of significant fuel failuresand/or waste treatment methods, etc.), and to reduce the summary uncertainty.

Let us briefly mention another important aspect of SFs application problem that has a significant impact on the final accuracy of characterization results. The uncertainty in the SF value derived in determination stage is influenced by the following factors: number of radiochemical analyses; dispersion or variance of data (regression is based on normal distribution) and determination method used (geometric mean, linear regression of logarithm, etc.). Among the possible sources, a limited number of radiochemical analyses are the most important contributors to the summary uncertainty associated with the SF estimation. To reduce the uncertainty, additional radiochemical analysis data may be needed. However, it is necessary to consider the following thing: "The number of data points is sufficient when investment in additional sampling and measurement produces no appreciable improvement in the statistical uncertainty" [16].

In the case of reactor shutdown and of those undergoing decommissioning, ratio of KN to DTM nuclide will change with the time. The $\mathrm{KN}$ such as ${ }^{60} \mathrm{Co}$ and/or ${ }^{137} \mathrm{Cs}$ will decay faster than the radionuclide of interest (alpha-activity of DTM, which have typically long halflives). Thus, decay correction shall be taken into account when developing and using the SFs. This also must be considered for legacy wastes (e. g. wastes that have been stored for a long period before characterization). 
In the case of those NPPs that have undergone major fuel damage incidents or accidents, different amounts of various radionuclides may have been transported and deposited to various areas inside and outside of the plant, as based on chemical transport properties and volatility of the elements involved. The most representative example of a situation, when it is necessary to take into account such factors affecting the SFs value, is 1986 Chornobyl accident and the peculiarities in formation of radioactive contamination at different distances from the accident epicentre [10]. In 2011, a technique for determination of specific activity of radionuclides in solid RAW of emergency origin on the access port monitor directly in the back of a truck was developed and approved [15]. The results of this work can be considered as a unique example of practical implementation of SF method to characterize solid waste, which were radioactively contaminated as a result of severe accident at NPP.

\section{Conclusions}

The analysis of information materials, revealing the basic principles of SFM, as applied to the tasks to be solved at the ChNPP, allows making the following conclusions:

1) to characterize solid RAW from the number of operational origin waste, received in specially equipped near-surface repository for solid radwaste (SESRSRW), from non-emergency Units or until April 1986, it is sufficient to follow the standard procedure for establishing the SF according to the results of data analysis for representative samples of solid RAW;

2) the most promising for implementation should be considered the procedure set out in ISO 21238 and, moreover, which is repeatedly recommended by the experts of WANO support mission;

3) the procedure for empiric establishing the SF should include: sampling of waste materials related from selected stream; laboratory analysis of radionuclides content; analysis of data for correlation results; selection of $\mathrm{KN}$ and estimation of SFs values for all DTM nuclides to be certified; systematic sampling to validate the SFs for "problematic" DTM nuclides and to reduce the summary uncertainty of certification results.

\section{References}

1. Selection of Technical Solution for the Management of Radioactive Waste. IAEA-TECDOC-1817. Vienna: IAEA, 2017, 114 p.

2. Nosovskyi A. V., Vasylchenko V. M., Klyuchnykov O. O., Yashchenko Ya. V. (2005) Decommission of Nuclear Power
Installations. Kyiv: Tekhnika, 288 p. (in Russ.)

3. IAEA-TECDOC-1537. Strategy and Methodology for Radioactive Waste Characterization. Vienna: IAEA, 2007, 182 p.

4. Alexandrova T. A., Blokhin P. A., Samoylov A. A., Kuryndin A. V. (2018) Analysis of the RW Radionuclide Composition in the Context of Long-term Safety of Its Disposal. Radioactive Waste, vol. 3, no. 2, pp. 44-51. (in Russ.)

5. Noe M., Muller W., Gens R., et al. (1998) Development of Methods to Provide an Inventory of Radiologically Relevant Radionuclides: Analytical Methods and Correlation of Data. Final Report. Luxenbourg: European Commission, 86 p.

6. Determination and Use of Scaling Factors for Waste Characterization in NPP. IAEA Nuclear Energy Series NW-T-1.18. Vienna: IAEA, 2009, 142 p.

7. ISO 21238:2007. Nuclear energy - Nuclear fuel technology Scaling Factor Method to Determine the Radioactivity of Low- and Intermediate-Level Radioactive Waste Packages Generated at Nuclear Power Plants. Geneva: International Organization for Standardization, 2009, $23 \mathrm{p}$.

8. ISO 16966:2013. Nuclear Energy - Nuclear Fuel Technology Theoretical Activation Calculation Method to Evaluate the Radioactivity of Activated Waste Generated at Nuclear Reactors. Geneva: International Organization for Standardization, 2013, 45 p.

9. Zherebtsov A. A., Varlakov A. P., Germanov A. V., Melnikov M. V., et al. (2017) Method for Estimating the Content of Alpha- and Beta-Emitting Radionuclides in Radwaste or Radiochemical Industry Using the Matrix of Gamma-emitting radionuclides. Nuclear and Radiation Safety, vol. 85, no. 3, pp. 1-9. (in Russ.)

10. Krasnov V.O., Nosovskyi A. V., Rudko V. M., Shcherbin V.M. (2016) Shelter Object: 30 Years after the Accident. Chornobyl: ISP NPP of NAS of Ukraine, 512 p. (in Ukr.)

11. Improvement of Radioactive Waste Characterization Systems at Existing Nuclear Power Plants of Ukraine and Procedures and Methodology of Clearance from Regulatory Control of Materials. Detail Task B3 report. Contract NSI/2014/341-505. Kyiv, 2017, 29 p. (in Russ.)

12. Methodology and practice in defining nuclide vectors. Final report of WANO Technical Support Mission at Chernobyl NPP (Slavutych, May 14-18, 2018). WANO-MC, 2018, 12 p. (in Russ.)

13. Criteria for acceptance of waste for burial in specially equipped near-surface repository for solid radwaste (SESRSRW). First stage of SESRSRW operation. Acceptance of RAW from SSE ChNPP PTLRW and PTSRW for burial in two symmetrical compartments of SESRSRW. Revision 5. Chornobyl, 2009, 38 p. (in Ukr.)

14. Plukis A., Remeikis V., Juodis L., Plukiene R., Lukauskas D., Gudeli A. (2008) Analysis of nuclide content in Ignalina NPP radioactive waste streams. Lithuanian J. of Phys, vol. 48, no. 4, pp. 375-379.

15. Specific activity of radionuclides in solid radwaste of Shelter Object. Procedure for conduct of measurements with using radiation monitor of automotive vehicle of 
RMAT-01-F type. PCM-ISP NPP-01-11. Chornobyl: ISP NPP of NAS of Ukraine, 2011, 32 p. (in Russ.)

16. Kashiwagi M., Muller W. (2000) Considerations on the activity concentration determination method for low-level waste packages and nuclide data comparison between different countries. Proc. Int. Conf. "Safety of Radioactive Waste Management" (Cordoba, 2000). Vienna: IAEA, pp. 175-179.

\section{О. В. Михайлов, В. О. Краснов, В. М. Безмилов}

Iнститут проблем безпеки АЕС НАН Украйни, вул. Кірова, 36а, м. Чорнобиль, 07270, Украйна

\section{Теоретичні та практичні аспекти застосування} методу масштабних коефіцієнтів для характеризації твердих радіоактивних відходів, що утворюються на АEC

Представлено короткий огляд найбільш відомих аналітичних і методичних матеріалів, присвячених питанням теорії і практики характеризації радіоактивних відходів (РАВ), які утворюються на АЕС. Розкрито базові принципи побудови методу масштабних коефіцієнтів (МК) та основні особливості його застосування в технологічному ланцюзі поводження з РАВ.

Показано, що фундаментом, який дозволяє використовувати методологію МК, $є$ наявність функціональних взаємозв'язків між активностями різних радіонуклідів, які напрацьовуються одночасно в ході кампанії реактора і забруднюють різні матеріали. У ході спеціального дослідження необхідно: провести відбір репрезентативної вибірки проб відходів від кожного потоку матеріалів, що підлягають радіаційному контролю; в умовах лабораторії визначити вміст усіх радіонуклідів, що підлягають паспортизаціі; використовуючи методи статистичного аналізу даних, розрахувати середні значення MK, які дозволяють за результатами гамма-спектрометріі активності реперних радіонуклідів (РР) оцінити в упаковках РАВ активність альфа- і бета-випромінюючих радіонуклідів, вимірювання яких вимагає значних матеріальних витрат і часу (радіонукліди, що важко вимірюються - РВВ).

Наочно продемонстровано вплив основних факторів $\mathrm{i}$ механізмів, що формують співвідношення вмісту РВВ/PР у твердих РАВ, що с характерним для реакторів типу РБМК. Визначено основні вимоги та процедури, які повинні бути відображені в методиці характеризації твердих РАВ Чорнобильської АЕС при паспортизації РВВ із використанням МК.

Ключові слова: АЕС, радіоактивні відходи, характеризація, масштабний коефіцієнт, реперні радіонукліди, важковимірювані радіонукліди, коефіцієнт кореляції.

\section{А. В. Михайлов, В. А. Краснов, В. Н. Безмылов}

Институт проблем безопасности АЭС НАН Украины, ул. Кирова, 3ба, м. Чернобыль, 07270, Украина

\section{Теоретические и практические аспекты применения метода масштабных коэффициентов для характеризации твердых радиоактивных отходов, образующихся на АЭС}

Представлен краткий обзор наиболее известных аналитических и методических материалов, посвященных вопросам теории и практики характеризации радиоактивных отходов (РАО), которые образуются на АЭС. Раскрыты базовые принципы построения метода масштабных коэффициентов (МК) и основные особенности его применения в технологической цепи обращения с РАО.

Показано, что фундаментом, позволяющим использовать методологию МК, является наличие функциональных взаимосвязей между активностями различных радионуклидов, которые нарабатываются одновременно в ходе кампании реактора и загрязняют различные материалы. В ходе специального исследования необходимо: провести отбор репрезентативной выборки проб отходов от каждого потока материалов, подлежащих радиационному контролю; в лабораторных условиях определить содержание всех радионуклидов, подлежащих паспортизации; используя методы статистического анализа данных, рассчитать средние значения МК, которые позволяют по результатам гамма-спектрометрического определения активности реперных радионуклидов (РP) в упаковках РАО оценить активность альфа- и бета-излучающих радионуклидов, измерение которых требует больших материальных затрат и времени (трудноизмеряемые радионуклиды - ТИР).

Наглядно продемонстрировано влияние основных факторов и механизмов, формирующих соотношение активностей ТИР/PР в твердых $\mathrm{PAO}$, характерное для реакторов типа РБМК. Определены основные требования и процедуры, которые должны быть отражены в методике характеризации твердых РАО Чернобыльской АЭС при паспортизации ТИР с использованием МК.

Ключевые слова: АЭС, радиоактивные отходы, характеризация, масштабный коэффициент, реперные радионуклиды, трудноизмеряемые радионуклиды, коэффициент корреляции.

Надійшла 11.02.2019 Received 11.02.2019 